proteínas. Objetivou-se avaliar a os efeitos de dieta hipocalórica, (contendo $60 \%$ das necessidades energéticas metabólicas basais), ao longo de periodo de seis meses, sobre as concentrações séricas de uréia e creatinina de cães obesos. Foram estudados 19 animais, com porcentagem de gordura corpórea maior que $20 \%$, de raças diversas, atendidos no Hospital Veterinário da UNISA no periodo de fevereiro a dezembro de 2002. Estes animais foram submetidos a uma avaliação inicial clínica completa, incluindo realização de urinálise de rotina e determinação de uréia e creatinina séricas, caracterizando função renal normal. A média de perda de peso obtida foi de $9 \%$ ao mês. Observou-se que durante o período de restrição calórica, as determinações de uréia e creatinina séricas permaneceram dentro dos padrōes de normalidade em $100 \%$ dos animais estudados. Analisando-se os valores de mediana da uréia sérica obtidos inicialmente e ao longo dos seis meses de restrição calórica, observou-se que não houve diferença estatisticamente significante entre eles $(p=0,77$, teste de Kruskal-Wallis). Por outro lado, analisando-se os valores de mediana de creatinina sérica obtidos inicialmente e ao longo dos seis meses de restrição calórica, observou-se diferença estatisticamente significante ( $\mathrm{p}=0,05$, teste de Kruskal-Wallis). Quando analisados isoladamente os valores de creatinina, observou-se uma elevação destes em relação ao mês zero, antes da restrição calórica, em $16(84 \%)$ dos 19 animais, sendo que quatro $(21 \%)$ apresentaram oscilações irregulares nos valores de creatinina sérica e apenas um $(5 \%)$ animal teve esse valor diminuído.. Concluiu-se que, na população de càes obesos ora estudada, a perda de peso promovida pela dieta de restriçào calórica promoveu alterações nos valores de creatinina sérica que, embora dentro da normalidade, apresentaram elevação no decorrer do processo de perda de peso, sugerindo aumento no catabolismo protéico dos animais estudados.

Kimura, K.C. ${ }^{1}$; Froes, T.R. ${ }^{2}$; Rosner, S.K. ${ }^{3}$; Coelho,B.M.P. ${ }^{3}$; Dagli,M.L.Z. ${ }^{4}$; Iwasaki,M. ${ }^{5}$

\section{9 - Peritonite bacteriana espontânea associado a cirrose hepática. Relato de caso}

1- Médica Veterinária do Hospital Veterinário da Faculdade de Medicina Veterinária da Universidade de São Paulo, São Paulo-SP

2- Doutoranda do Departamento de Cirurgia da Faculdade de Medicina Veterinária da Universidade de São Paulo, São Paulo-SP

3- Médicas Veterinárias do Hospital Veterinário da Faculdade de Medicina Veterinária da Universidade de São Paulo, São Paulo-SP

4- Professora Doutora do Departamento de Patologia da Faculdade de Medicina Veterinária da Universidade de São Paulo, São Paulo-SP

5- Professor. Titular do Departamento de Cirurgia da Faculdade de Medicina Veterinária da Universidade de São Paulo, São Paulo-SP

O figado têm a função de transformar bioquimicamente substâncias tóxicas, produzir bile, destruir células mortas e outros resíduos sanguíneos, além de assimilar e armazenar substâncias nutritivas. Os pacientes hepatopatas e cirróticos podem desenvolver peritonite bacteriana espontânea, levando a um mau prognóstico. Quanto a fisiopatogenia, a possivel predisposição ao quadro infeccioso por diminuir as proteinas totais e os níveis séricos do sistema complemento, quando associado a hipomotilidade intestinal, favorece o hipercrescimento bacteriano. Desse modo, ocorre a translocação de bactérias (geralmente entéricas) do lúmen intestinal para os linfonodos mesentéricos, progredindo para o ducto torácico e linfático, disseminando para a corrente sangüinea. Por meio da corrente sanguínea, as bactérias passam pelo fígado e pela cápsula de glisson, obtendo acesso ao líquido ascítico, causando a peritonite bacteriana espontânea. Sabe-se que em pacientes humanos com cirrose hepática, a probabilidade do desenvolvimento de peritonite bacteriana espontânea está em torno de $10 \%$.Os objetivos deste relato é demonstrar a existência da peritonite bacteriana espontânea em um animal da espécie canina com cirrose hepática, relatar a eficiência do exame ultra-songráfico na abordagem de cães com abdome agudo e discutir os diferentes aspectos da imagem ultra-sonográfica da cirrose no cão. No dia 27 de Janeiro de 
2003, foi encaminhado ao hospital veterinário, um cão, da raça Doberman, macho, 6 anos com suspeita de torção gástrica. $\mathrm{O}$ animal apresentava-se anoréxico e a palpação abdominal observou-se um aumento de volume abdominal em região epi-mesogástrica. Ao atendimento foi realizado um exame radiográfico abdominal em que observou-se homogeniedade da cavidade abdominal sem sinais radiográficos de torção gástríca. $\mathrm{O}$ animal foi então encaminhado ao exame ultra-songráfico sendo visibilizado: dificuldade de avaliação do parênquima hepático, presença de múltiplos nódulos hipoecóicos em alvos entremeados pelo parênquima e contorno irregular; presença de massa arredondada, heterogênea e cavitária de aproximadamente $6,0 \mathrm{~cm}$ de diâmetro em região epi-mesogástrica sugestiva de linfonodo peri-hepático severamente hiperecóico. Foi realizado uma citologia da massa e do líquido abdominal em que verificou presença intensa de neutrófilos tóxicos sugerindo um processo infeccioso severo e peritonite. Ao hemograma o animal apresentava neutrofilia com desvio degenerativo à esquerda. $\mathrm{O}$ animal foi encaminhado a laparotomia exploratória devido a suspeita de peritonite. Na laparotomia não observou-se ruptura de alça ou estômago, sendo visualizado um grave acometimento hepático (atrófico, irregular e com multiplos nódulos) e sinais difusos de peritonite. Devido a estes achados o proprietário optou pela eutanásia e o animal foi encaminhado ao Departamento de Patologia para ser realizado exame necroscópico. O diagnóstico final mostrou um quadro de cirrose hepática associada ao quadro de peritonite bacteriana espontânea. A importância do relato é demonstrar que os casos de cirrose podem apresentar a peritonite espontânea bacteriana sugerindo mau prognóstico para o paciente.

\section{0 - Megaesôfago em gato. Relato de caso}

Ushikoshi, W.S.' ; Lorigados, C.A.B. ${ }^{2}$; Penha, M.G.B ${ }^{3}$
1- Professor de Clínica de Pequenos Animais da Faculdade de Medicina Veterinária da Universidade de Guarulhos e Universidade Santo Amaro, São Paulo-SP

2-Professora de Diagnóstico por Imagem da Faculdade de Medicina Veterinária da Universidade de Guarulhos e Universidade Santo Amaro, São Paulo-SP

3- Graduanda da a Faculdade de Medicina Veterinária da Universidade de Guarulhos, Guarulhos-SP

O presente trabalho descreve um felino, sem raça definida, fêmea, de três meses de idade, com histórico de regurgitação há aproximadamente duas semanas. O proprietário negava qualquer alteração além dos quadros de "emese", principalmente após a alimentação, de conteúdo alimentar não digerido e formato tubular. Ao exame físico não foi observada desidrataçào ou caquexia e as funções vitais estavam dentro dos parâmetros normais. Foi realizado exame radiográfico de esôfago simples e esofagograma onde se observou dilataçào esofágica total. $\mathrm{O}$ tratamento preconizado foi cimetidina (10 mg/ $\mathrm{kg} / \mathrm{PO}$, a cada 12 horas) e cisapride $(0,5 \mathrm{mg} /$ $\mathrm{kg} / \mathrm{PO}$ ) além do manejo alimentar com dieta pastosa, mantendo o animal em postura bipedal. Após 30 dias, houve diminuição dos eventos de regurgitação e após três meses o paciente se apresentava assintomático. Foi realizado exame radiográfico controle onde nào evidenciou a dilatação esofágica. Atualmente, com um ano de idade, $\mathrm{o}$ animal não está sendo medicado $\mathrm{e}$ não apresenta sintomas de regurgitação. $\mathrm{O}$ megaesôfago é caracterizado por uma dilataçào total do esôfago e sua ocorrência em gatos é considerada rara quando comparada em càes, acometendo cerca de $0,05 \%$ dos felinos atendidos. Os principais sintomas variam desde regurgitação, pneumonia ou ambos. Dentre as causas incluem-se a congênita, secundária a esofagite ou doença obstrutiva, decorrente de doença neuromuscular ou ainda idiopática, sendo esta última considerada mais comum. Uma vez que a diminuição da motilidade esofagiana não pode ser avaliada e os aspectos radiográficos não foram compativeis com persistência de arco aórtico direito ou obstrução esofágica, foi realizado uma lista de possiveis diagnósticos de megaesôfago congênito, secundário a esofagite por refluxo ou idiopático. $\mathrm{O}$ tratamento com cisapride e cimetidina foi indicado para aumentar a motilidade esofágica e diminuir a secreçào gástrica, respectivamente, além de evitar ou agravar uma possível esofagite de refluxo. Em càes, os pró-cinéticos nào sào considerados efetivos para o tratamento do megaesôfago, por outro lado, como o esôfago dos felinos é constituído principalmente de 